\title{
As escolas e o ressurgir da filosofia no renascimento carolíngio
}

Manoel Vasconcellos ${ }^{1}$

\begin{abstract}
Resumo:
Com o fim do Império Romano, a estrutura educacional foi abalada. A religião cristã foi capaz de preservar a tradição da antiguidade. Pouco a pouco uma nova civilização vai surgindo, erguendo-se a partir de três bases: a cultura romana subsistente, o impacto dos bárbaros e a religião cristã. No reino dos francos, Carlos Magno faz renascer a cultura, através de sua aliança com a Igreja. Surgem novas escolas e há uma retomada das artes liberais; a dialética, particularmente, será a base para a retomada dos debates filosóficos, mesmo inseridos em polêmicas teológicas, tais como a discussão em torno da predestinação divina que colocou em lados opostos Godescalco e Scoto Eriúgena.
\end{abstract}

Palavras-chave: Dialética. Predestinação. Renascimento.

\begin{abstract}
:
With the fall of the Western Roman Empire, the educational structure was shaken. Christianity was able to preserve the classical antiquity tradition. Little by little a new civilization emerged, which was built on three bases: the subsisting Roman culture, the Barbarian impact and Christianity. In the kingdom of the Franks, Charlemagne revived culture through his alliance with the Church. New schools were opened and, as a result, the study of the liberal arts was revived; dialectics, in particular, would be the basis for the resumption of philosophical debates, even when accompanied by theological controversies, such as the discussion on divine predestination that placed Godescalco and Scoto Eriúgena on opposing sides.
\end{abstract}

Keywords: Dialectics. Predestination. Renaissance.

No final da antiguidade clássica, o período que sucedeu às invasões bárbaras que, pouco a pouco, colocaram abaixo o outrora pujante Império Romano, foi marcado por generalizada desconstrução. As diversas instituições, inclusive educacionais, viram ruir suas já enfraquecidas

\footnotetext{
${ }^{1}$ Professor do Programa de Pós-Graduação em Filosofia da Universidade Federal de Pelotas; doutor em Filosofia (PUC-RS)
} 
estruturas. É paradigmático o assombroso lamento do Papa Gregório Magno (590 - 604) ao descrever, em seus Diálogos, cidades despovoadas, aldeias arrasadas, igrejas queimadas, campos abandonados que pareciam antever o final dos tempos. No entanto, a religião cristã, mesmo abalada, pôde oferecer uma certa resistência, mantendo-se como condutora de esperanças em tempos pouco alvissareiros. No vácuo de poder que os bárbaros não conseguiram preencher, a Igreja acaba por assumir funções que não the eram tão próximas.

O colapso da organização política do Império Romano deixara um grande vácuo que nenhum rei bárbaro ou general poderia preencher. Ele foi preenchido, contudo, pela Igreja, que assumiu a função de tutora e legisladora dos novos povos. Os padres latinos - Ambrósio, Agostinho, Leão e Gregório - foram, concretamente, os pais fundadores da cultura do Ocidente, na medida em que, por meio do árduo trabalho desses homens, os distintos povos do Ocidente puderam ser incorporados à comunidade espiritual da cristandade, adquirindo, dessa forma, uma cultura comum”. (DAWSON, 2016, p. $51)$.

Os reinos bárbaros, evidentemente, possuíam poder militar e econômico, mas não tiveram condições de gerir as esferas educacionais e culturais, como um todo, de modo que a cidadania, se assim podemos dizer, estará relacionada à Igreja e não ao Estado bárbaro (cf. DAWSON, 2016, p. 57). Somente o distanciamento temporal permitiu que vislumbrássemos a confluência da derrocada de uma civilização e o nascimento de uma outra, formada no entrelaçamento das diferenças e sobreposições da cultura romana subsistente, do impacto trazido pelos bárbaros e da religião cristã. Instaurava-se um processo complexo, localizado na primeira metade do medievo, em que houve, por um lado, um retrocesso cultural, mas, de outro lado, é possível perceber o nascimento e desenvolvimento de uma nova civilização que comportava, como salienta Righi (2016, p.17) "padrões inéditos de liberdade e de dignificação da vida". 
Num tal cenário, os mosteiros exercerão uma vasta influência religiosa e, concomitantemente, educacional. Embora a criação de escolas não fosse o escopo da atividade monacal, as circunstâncias advindas do quase desaparecimento da educação formal, fizeram com que os monges assumissem tal desafio. Por saberem ler e escrever, desempenharão um papel importante, suprindo uma área que não era considerada relevante para os conquistadores bárbaros, uma vez que a educação, com este caráter formativo mais amplo, não fazia parte da sua tradição. Os mosteiros, com suas bibliotecas serão responsáveis por preservar a tradição clássica, a qual ressurgirá, impermeada dos valores cristãos, marcando decisivamente a cultura ocidental. O historiador Richard Dawson (2016, p. 82) evidencia, particularmente, a proeminência do monasticismo irlandês, na medida em que seus mosteiros não foram apenas locais de oração, mas acabaram por constituir-se em escolas e centros de aprendizagem.

Em que pese o protagonismo dos monges irlandeses, a alavanca decisiva para a retomada dos processos educacionais, filosóficos e teológicos no medievo foi acionada por Carlos Magno (742 - 814) e Alcuíno de York (735 - 804). Carlos Magno é figura ímpar na história, reunindo, num só personagem, o guerreiro valente e conquistador, o hábil político, o chefe de estado, o cristão convicto e o homem apaixonado pela educação e pelos debates filosófico-teológicos. Tornando-se governante, obtém, ao longo de quase cinquenta anos, uma série de vitórias em que a força militar vai conquistando povos e regiões, sempre acompanhada de um ideal de expansão do cristianismo, uma vez que o rei dos francos se vê como portador de uma missão divina que o impele a empenhar-se na difusão da religião cristã. É digno de menção que quando conquistava uma determinada região, ele exigia de seus habitantes a conversão à religião cristã (cf. DHONDT, 1978, p.30).

Carlos Magno herdara de seu pai, Pepino, o Breve (714 - 768) um poderoso exército que, sob seu comando será sempre mais vitorioso, graças às selas de seus cavalos, a armadura que cobria seus soldados e a estratégia militar de seu comandante. Seu engenho militar fez com que conquistasse 
vastos territórios, tais como a Frísia, Saxônia, Francônia, Baviera, reino lombardo, Gótia e Marca da Espanha (cf. GENET, 2002, p.400). Sabia, contudo, que a força militar, mesmo sendo suficiente para as muitas conquistas, não seria suficiente, por si só, para manter e administrar um império marcado pela vastidão territorial e diversidade linguística e cultural. Carlos Magno buscou na Igreja, única instituição capaz de promover cultura e formar pessoas, o apoio para seu projeto. $\mathrm{O}$ imperador não hesita em fazer uso das estruturas eclesiásticas, tomando-as como apoio fundamental para a construção da estrutura administrativa do império. As relações dos francos com a Igreja vinham, há tempos, sendo construídas. Lembremos, por exemplo, que já Pepino, o Breve fora coroado, em 751, com a anuência e a bênção papal, através de uma consagração religiosa, presidida por São Bonifácio (c.672 - c.754). Carlos Magno, por seu turno, não dispensará a decisiva colaboração da Igreja na administração do seu vasto império:

A Igreja estava dotada, também durante a época carolíngia, de substanciais características religiosas e espirituais, mas possuía, ao mesmo tempo, uma enorme influência econômica e constituía um elemento indispensável na gestão da administração do estado. Os bispos e abades desempenhavam funções similares aos condes. Tomavam parte ativa nas assembleias em que as leis eram discutidas e promulgadas e o alto clero exercia frequentemente uma autêntica preponderância. (DHONDT, 1978, p.51-2, tradução nossa).

De fato, o rei dos francos, precisava do apoio da Igreja para a manutenção e consolidação de seus ideais políticos e religiosos, mas também o Papa precisava da proteção dos francos, uma vez que o Imperador do Oriente, seja pela distância, seja pelos problemas internos que enfrentava, não estava em condições de dar o amparo prometido ao sucessor de Pedro. A aliança entre Carlos Magno e a Igreja, faz com que a segunda aceite o forte controle do primeiro nas questões eclesiásticas, ao mesmo tempo que confere um caráter teocrático ao império dos francos, expressando "tanto a nova concepção de cristandade como máxima unidade 
social quanto o caráter sagrado do governante como chefe divinamente designado do povo cristão" (DAWSON, 2016, p.110). É interessante notar que Carlos Magno não pretende romper com Roma, nem mesmo estabelecer uma supremacia da Igreja dos francos; antes, ele incorpora e se esforça por difundir a doutrina cristã, tal como procede de Roma, entendendo, porém, que a condução da Igreja, como tal, é tarefa, primordialmente sua e não do Papa. A coroação do imperador pelo Papa Leão III (750 - 816), ocorrida no Natal de 800, em Roma, sintetiza e simboliza esta monarquia cristã que pretende ser a reconstrução do império romano, agora sob a condução dos francos. O imperador, em consonância com os intelectuais a quem sempre consultava, concebe, desse modo "uma monarquia profundamente cristã na qual a questão dos dois poderes (do rei e da Igreja) está resolvida antes de ter sido efetivamente colocada por um papado decadente" (GENET, 2002, p.400).

Esse entrelaçamento de forças favorecerá a construção daquele que ficou conhecido como o projeto cultural carolíngio. Em tal projeto Alcuíno de York desempenhará um papel singularíssimo. Sua formação encontra-se intimamente ligada à escola da Catedral de York, onde teve contato com o pensamento de Aristóteles, Cícero, Gregório Magno, João Crisóstomo, Cassiodoro, Boécio, Beda, Prisciano e Virgílio, entre outros. Mais tarde, na composição de suas obras, perceber-se-á a grande influência de autores como Ambrósio, Agostinho, Gregório Magno, além de Isidoro de Sevilha (cf. VEYARD-COSME, 2006, p.33).

Em 781, Carlos Magno encontra Alcuíno em Parma e convida-o para ser o mestre da escola palatina. Aceito o convite, o monge de York permanece na corte até 790, quando volta a Grã-Bretanha. Três anos depois, retorna ao convívio de Carlos Magno, sendo responsável pela instauração do grande projeto cultural que caracterizou a época carolíngia (cf. OLIVEIRA e SIBIN, 2013, p. 20). Alcuíno, nessa ocasião, estava por volta dos 50 anos de idade. Já tinha tido a experiência, em York, de congregar intelectuais e formar bibliotecas. Este é o desafio que, uma vez mais, terá pela frente: 
A verdadeira grandeza de Alcuíno resulta muito mais de sua pessoa e de sua obra civilizadora do que de seus livros. Ela se revela em todas as suas cartas e nas passagens de seus tratados em que se exprimem sua admiração profunda pela cultura antiga e sua vontade de mantê-la. $\mathrm{O}$ espírito de seus mestres de York sobrevive nele e anima toda a sua obra. Seu mestre Egberto, tinha o costume de dizer que as artes liberais não eram obra dos homens, mas de Deus que as criou na natureza, onde os homens só precisavam encontra-las. Isso pelo menos os antigos fizeram, que vergonha seria então, para os cristãos, não serem sequer capazes de conservá-las. Alcuíno nunca esqueceu essa lição, de que sua vida foi a aplicação. (GILSON, 1995, p.228-9).

Ajudado por Alcuíno, o imperador reúne, junto à escola palatina, intelectuais provenientes de diferentes partes da europa. Destacam-se, além do próprio Alcuíno, Paulo Diácono, Pedro de Pisa, Paulino de Aquiléia, Agobardo e Teodulfo de Orléans. Auxiliado por eles, o imperador empenhase pessoalmente na reforma litúrgica e, até mesmo, na formação do clero. Carlos Magno é um singular exemplo histórico de governante com pujante poder político, econômico e militar e que se dedica fortemente à divulgação das artes, almejando, ao mesmo tempo, ampliar a qualidade da educação formal. Alcuíno está em plena sintonia com o projeto do imperador, antevendo a formação de uma "nova Atenas", mais nobre do que a antiga, pois a Atenas dos filósofos, ao contrário da Atenas carolíngia, não era enriquecida pelo ensinamento de Cristo e os dons do Espírito Santo. Para que tal projeto tivesse êxito, fez com que importantes textos de mosteiros ingleses chegassem à corte; além disso, ele mesmo redigiu manuais, incentivou os trabalhos dos copistas e se ocupou do desenvolvimento das escolas anexas às catedrais, tal como fora planejado por Carlos Magno (cf. BROCCHIERI e PARODI, 1998, p.72).

Entre as iniciativas do imperador para obter o florescimento cultural desejado encontram-se, por exemplo, as costumeiras reuniões com os sábios na escola palatina, o especial convite aos clérigos para que se dedicassem às artes do trivium (dialética, gramatica e retórica) e do quadrivium (aritmética, 
geometria, astronomia e música), além da recomendação a bispados e mosteiros para que estendessem o ensino das letras a todos aqueles que estavam aptos para seu aprendizado (cf. VITORETTI e OLIVEIRA, 2002). O centro irradiador de toda essa renovação é, sem dúvida, a escola palatina, em que "os melhores mestres instruiriam os melhores alunos, para lá enviados de todas as partes" (GUENÉE, 2002, p.270). Constitui-se, na verdade em um grande centro intelectual que congregou, num mesmo espaço e com o mesmo escopo, intelectuais e membros da corte, clérigos e leigos. A escola promoveu a correção das letras latinas, além de proporcionar um vivaz debate em torno de questões teológicas, tão apreciadas pelo imperador, em que a filosofia renascente desempenhará um papel fundamental. Um importante desdobramento da incursão pelos textos latinos foi o surgimento da minúscula carolíngia que simplificava o processo de escrita, substituindo os diversos estilos originados da degeneração da escritura romana.

A escola palatina é centro irradiador de cultura, mas está inserida em um projeto bem mais vasto, posto em execução desde que o imperador, através de uma capitular de 798 ordena a abertura de escolas nas catedrais e mosteiros, a fim de que as crianças, mesmo aquelas que não possuíam berço nobre, tivessem acesso aos ensinamentos religiosos, e às artes, sobretudo a gramática. Tal iniciativa foi ratificada pelo concílio de Chalon, de 813. É conhecido um texto de Theodolfo, sucessor de Alcuíno em que recomenda que os padres abram escolas, atendendo crianças com toda a caridade, sem receber pagamento (cf. KNOWLES, 2000, p.66).

David Knowles (2000, p. 67), chama a atenção para o caráter bastante elementar da proposta de estudos, razão pela qual não seria, em si mesma, suficiente para o estabelecimento de estudos mais elevados, sobretudo no que tange à Filosofia. No entanto, reconhece o estudioso que mesmo assim, foi a partir das escolas do império carolíngio que se desenvolveu a vida intelectual da idade média. Carlos Magno e Alcuíno foram responsáveis por um verdadeiro renascimento filosófico, surgido no bojo de seu projeto de renovação e expansão cultural. De fato, o incremento 
dos estudos levou a uma retomada das artes liberais. Alcuíno que já escrevera tratados sobre as artes, entende-as como as sete colunas que sustentam a sabedoria. Dessa forma, insere o aprendizado em uma dimensão espiritual, até mesmo por poder relacionar o número das artes com os sete dons do Espírito Santo, as sete virtudes, além de ser um número importante do livro do Apocalipse: sete Igrejas, sete espíritos de Deus, sete cabeças. (cf. QUEIROZ, 1999, p. 26).

Como consequência de todo esse processo, a partir das escolas, se faz presente uma retomada do trivium; ao lado da gramática e da retórica, a dialética ganha novo fôlego e aparece como instrumento fundamental para sustentar os debates filosóficos, mesmo que bastante inseridos em questões teológicas. Os textos que embasavam o estudo do trivium eram, precipuamente, as gramáticas de Prisciano e Donato; para o estudo da retórica, utilizava-se Cícero e Quintiliano. A dialética, por seu turno, era ensinada a partir da Isagoge de Porfírio, dos textos lógicos de Aristóteles, além dos comentários que Boécio fez a tais obras. É a dialética que, mais efetivamente, vai colaborar para o ressurgimento filosófico. Ela será o sustentáculo das diversas polêmicas da época carolíngia em que a filosofia estará presente, ainda que, como já foi dito, inserida em questões de cunho teológico. Assim, teremos o debate eucarístico que envolveu Pascácio Radberto, Ratrammo, Rabano Mauro e Godescalco, entre outros. Há também a discussão sobre o nada e as trevas de Fredegiso de Tours, a inusitada questão da racionalidade e dignidade dos supostos homens com cabeça de cão, os cynocephalis, tal como fora defendido por Agostinho em A Cidade de Deus (livro XXVI, capítulo VIII, 1) e, agora, retomado por Ratrammo.

A fim de mostrar como ocorreu e o que representou o retorno efetivo da reflexão e produção filosóficas, a partir do renascimento carolíngio, atentemos sobre uma das polêmicas surgidas. Tomaremos como paradigma, a querela sobre a predestinação. Nosso intento é, a partir de algumas passagens do De praedestinatione liber de Scoto Eriúgena (815 - 877), evidenciar o papel destacado do trivium, especialmente a dialética, como 
fundamento para afirmar concepções e corrigir eventuais erros. Em torno da contenda sobre a predestinação estiveram, de um lado Godescalco (808 867), de outro Ratrammo (+ c. 870), além de Scoto Eriúgena. Para ser mais preciso, se deve dizer que a celeuma não se deu unicamente por causa da predestinação, uma vez que, pelo menos duas outras concepções estavam em jogo: o livre arbítrio e a redenção do homem.

A fim de facilitar a compreensão, situemos muito brevemente, os principais pontos da doutrina de Godescalco, uma doutrina adjetivada por Rabano Mauro, como sendo perniciosa. O monge Godescalco afirmava que há uma divina predestinação que compreende tanto o bem quanto o mal, de modo que todos os homens estão predestinados à salvação ou à condenação eternas, não obstante suas obras. Além disso, Godescalco entende que boa parte da humanidade, incluídos os clérigos, não desfrutará da beatitude eterna. O que o autor quer, de fato, enfatizar é que a salvação não pode ser alcançada pelo esforço humano, mas unicamente pela graça e sabedoria divinas. Não havendo predestinação, o caráter absolutamente imutável, próprio da divindade, estaria comprometido, uma vez que as decisões divinas estariam condicionadas às ações humanas, algo absurdo, consoante Godescalco.

O autor está convicto da correção de sua tese, pois julga encontrar guarida nos escritos de Santo Agostinho. As possíveis fontes agostinianas de Godescalco seriam De civitate Dei, De diversis quaestinobus ad Simplicianum, Enchridium, bem como Contra duas epistolas pelagianorum, ou seja, fundamentalmente, as obras do último período do hiponense em que, marcado pelo combate aos pelagianos, que afirmavam ser o homem o grande responsável por sua salvação, o bispo de Hipona afirma e enfatiza o papel absolutamente central da Graça. O homem caiu por si só, mas não é capaz de reerguer-se sem o auxílio divino.

As ideias de Godescalco, mesmo tendo recebido diversas repreensões e condenações, são acolhidas com simpatia por setores da própria Igreja. No contexto teocêntrico do medievo, contudo, é compreensível que a concepção de Godescalco em torno da dupla predestinação acabe por suscitar 
inquietações que extrapolam o âmbito propriamente religioso. Godescalco, de certa forma, vai de encontro ao espírito de expansão do cristianismo, tão característico da época carolíngia: afinal, para que levar o evangelho a outros povos se isso não será determinante para a salvação, uma vez que a condenação ou salvação já estão, de antemão, determinadas e independem do conhecimento ou não do cristianismo? Numa sociedade marcada pelos valores religiosos, em que a existência de uma vida após a morte não é posta em dúvida, alguém poderia perguntar qual o sentido de ser virtuoso, inclusive nas relações com os superiores ou mesmo com o estado, se o destino eterno já está determinado, independentemente do bem feito ou do mal evitado, mesmo no âmbito das relações políticas, econômicas e sociais.

Até mesmo Carlos II, neto de Carlos Magno, governante de uma parte daquele que foi o grande império construído por seu avô, teve ciência das ideias de Godescalco e ficou preocupado com a sua repercussão. É por solicitação do monarca que Hincmaro convida Scoto Eriúgena para combater as concepções divulgadas por Berengário e seus simpatizantes. Eriúgena que já manifestara posição contrária à ideia da dupla predestinação, é convidado a elaborar sua crítica de um modo mais sistemático e abrangente. E é o que procura fazer em seu De praedestinatione liber, obra elaborada por volta de 850 .

Não seria possível no âmbito do presente estudo, uma exposição detalhada da obra de Scoto Eriúgena sobre a predestinação divina, razão pela qual vamos nos ater a alguns momentos mais significativos para o que temos em vista. Desde as primeiras linhas já fica evidenciado o que o autor deseja defender. Ele cita a passagem da carta de Tiago 1,17 em que é dito que os dons preciosos procedem do alto, do pai das luzes. Ora, alguns estudiosos, como Mainoldi (2003, p. 213), observam que também o Pseudo Dionísio utilizou esta passagem, no De coelesti hierarchia, para referir a simplicidade divina. É esta mesma simplicidade divina que servirá de alegação a Eriúgena para fundamentar sua concepção, consoante a qual, não pode provir de Deus a predestinação ao mal, uma vez que na divindade não 
há variação, nem mudança, não sendo possível a predestinação do pecado e da morte.

Eriúgena faz questão de fundamentar seu ponto de vista de modo que as conclusões obtidas decorram de uma sólida construção argumentativa, mostrando já de início que a obra vai se assentar não somente na fé, mas também na dialética. Tal argumentação permitirá a identificação do erro de seu oponente, uma vez que ao postular uma dupla predestinação, Godescalco estaria interpretando de maneira dualista os termos que dizem respeito ao que é unitário. De fato, sendo Deus atemporal não poderia predestinar uma vez que pré implica uma anterioridade e, em Deus não há nem antes, nem depois.

Identificando, à luz de Agostinho, a verdadeira filosofia com a verdadeira religião, Scoto Eriúgena apresenta um harmonioso quadrivium filosófico, constituído pela divisão, definição, demonstração e resolução:

A primeira destas [divisão], dividindo decompõe a unidade na multiplicidade; a segunda [definição], definindo recolhe na unidade a multiplicidade; a terceira [demonstração], demonstrando resolve as questões pendentes através das evidentes; a quarta, [resolução] separando reconduz as questões complexas às simples. (Scoto Eriúgena, De praedestinatione liber I, 358 A - tradução nossa).

Note-se que o quadrivium de Eriúgena não é aquele mesmo clássico das artes liberais, formado pela geometria, aritmética, astronomia e música. O quadrivium em questão é constituído pelas quatro partes da dialética, ou seja, a disciplina da argumentação e seu domínio para o alcance da verdade. A argumentação dialética, no caso, pretende esclarecer pontos, fundamentalmente, teológicos. O apurado exame dos textos das Escrituras e dos Padres, juntamente com a dialética, constituem a base teórica a partir da qual se desenvolvem os diversos temas abordados no tratado sobre a predestinação. A autoridade e a razão, ainda que distintas, estão ambas a serviço da verdade. Entre os Padres, é claro que Agostinho receberá maior atenção, não apenas pelo seu destaque como autoridade, mas também por 
ser o referencial teórico utilizado por Godescalco para fundamentar sua doutrina, mas enquanto Godescalco tem em conta, fundamentalmente, os textos da última fase da produção intelectual agostiniana, Eriúgena faz uso dos primeiros tratados do Agostinho recém convertido, ainda muito marcado pela tradição filosófica do neoplatonismo (cf. FLASCH, 2002, p. 45).

Eriúgena, contudo, não se restringe aos textos do hiponense. Ele é um conhecedor da língua grega, razão pela qual pôde ler muitos dos Padres Gregos, inclusive Orígenes, além de ter traduzido, para o latim, o Nomes Divinos, o Hierarquia Celestial e o Hierarquia Eclesiástica do Pseudo Dionísio. Pois bem, Eriúgena acusa seus adversários de não compreenderem que o verbo grego ópw [óro] _corresponde a três verbos latinos vejo (video), defino (diffinio) e destino (destino). Analogamente ocorre com prevejo, predefino e predestino. Em todos estes casos, o desconhecimento do grego faz com que os verbos - e seus compostos - sejam traduzidos com a palavra praedestino, enquanto poderiam ser usados outros termos, tais como praevideo ou praediffinio, uma vez que todas estas palavras expressam o sentido de um mesmo termo grego.

Assim sendo, quando se fala da divindade, deve-se entender predestinar, predefinir e prever como sinônimos. Ora, raciocina Eriúgena, em Deus todas as coisas são. Elas são aquilo que por Ele foi previsto, predestinado, predefinido e conhecido antecipadamente. Aquelas coisas, porém, que não procedem de Deus e, precisamente por isso, em realidade, não são, tais coisas não foram nem predestinadas, nem predefinidas, nem previstas e nem conhecidas antecipadamente por Deus. É por isso que se pode dizer que a vida criadora não criou, de modo algum, a morte da vida criada:

o pecado é a morte da alma... e, portanto, a Vida não criou a morte da vida. A morte é pena do pecado, mas Deus não criou a morte e, portanto, não criou a pena ...A pena é castigo, mas Deus não criou a pena e, portanto, não criou o castigo. (Scoto Eriúgena, De praedestinatione liber XVIII $432 \mathrm{C}$ - tradução nossa).

Filos. e Educ., Campinas, SP, v.10, n.2, p.249-263, maio/ago. 2018 - ISSN 1984-9605 
O autor do De praedestinatione liber se vale de texto do Enchiridion de Agostinho, a fim de mostrar como o Bispo de Hipona utilizou o termo predestinação com o sentido de previsão. De fato, Agostinho faz uso de expressões, tais como, quos praedestinauit ad inteitum, aqueles predestinados à ruína, ou expressões semelhantes. No entanto, há que bem entendê-las. Sabedor de que Agostinho era utilizado por Godescalco e seus seguidores, Eriúgena deixa claro que reconhece firmemente a autoridade do hiponense, a quem qualifica como piissimus doctrine pater, pí́ssimo pai do ensinamento, entre outros títulos.

Manifestado seu respeito e admiração por Agostinho, explica que a expressão aqueles que justamente predestinou à pena, não é utilizada pelo hiponense da mesma maneira como utiliza aqueles que benevolamente predestinou à graça, pois a predestinação à pena não é obra da Graça, mas da Justiça divina, tanto que Agostinho fala em iuste praedestinavit ad poenam e praedestinatio dei que in bono est gratie, evidenciando, consoante Eriúgena, que a predestinação dos castigos deve ser entendida como uma antífrase; não haveria, pois uma dupla predestinação; a punição dos maus não tem relação com a graça, mas com a justiça que é um bem. Eriúgena examina diversas passagens de Agostinho, no intento de mostrar a pertinência de seu raciocínio, concluindo que não deixa de haver uma certa semelhança entre o procedimento divino e as leis humanas, pois elas, ao estabelecerem punições, não estão impelindo ninguém ao crime; elas buscam tão somente frear o ímpeto dos maus e, nesse sentido, mostrariam mais misericórdia do que, propriamente, castigo. As leis temporais buscam a correção dos culpados. Ora, conclui Eriúgena, se assim são as coisas para as leis transitórias, muito mais o serão para as leis eternas, plenas da força imutável da piedade e da justiça divinas. $\mathrm{Na}$ verdade, para Eriúgena, em Deus a presciência e a predestinação estão integradas. A linguagem humana, por causa de suas limitações, distingue aquilo que, em Deus, é uma perfeita unidade. A predestinação divina nada mais é do que a lei eterna de todas as naturezas que leva em conta a queda da mutável criatura humana, ofertandolhe a restauração de sua misericórdia e sua graça. 
Eis aí, traçadas em linhas muito gerais a concepção de Godescalco e a crítica de Scoto Eriúgena. Não tivemos a pretensão de expor em minúcias os argumentos de um e de outro. Na verdade, o que queríamos acentuar é que tais divergências mostram claramente que, as circunstâncias históricas, advindas da retomada do trivium, nas escolas surgidas com o renascimento carolíngio, propiciaram um espaço de discussão em que gramática, retórica e, sobretudo, dialética serão instrumentos preciosos para elucidações conceituais e construções argumentativas em torno de problemas que talvez até possamos relativizá-los quanto a sua relevância filosófica, mas que eram problemas em voga e a Filosofia, renascida, após um longo período de pouca fecundidade, foi trazida à tona para justificar as diversas teses. É importante notar que o uso das artes liberais, particularmente da dialética, já aparece, sobretudo com Scoto Eriúgena, como elemento importante na construção argumentativa. É oportuno recordar que, consoante Eriúgena a fé sempre tem prioridade em relação à razão; no entanto, a razão é prioritária em relação à autoridade, uma vez que esta pode equivocar-se. É certo que a autoridade não é desprezada, mas também não é tomada como elemento único e imprescindível para a busca da verdade.

A retomada do trivium aperfeiçoa a técnica filosófica, razão pela qual podemos dizer que o pensamento filosófico surgido no contexto do renascimento carolíngio foi importante, no mínimo, como preparação do terreno para as discussões filosóficas, talvez mais amadurecidas e melhor instrumentalizadas que se seguirão após o século XI.

\section{Referências}

AUGUSTINUS HIPPONENSIS. Opere Omnia. Patrologiae Latinae. Disponível em: https://www.augustinus.it/latino/index.htm. Acesso em: 25 de novembro de 2017.

BROCCHIERI, Mariateresa; PARODI, Massimo. Storia dela Filosofia Medievale. 2 ed. Roma-Bari, 1998.

DAWSON, Christopher. Criação do Ocidente. São Paulo: É Realizações, 2016.

Filos. e Educ., Campinas, SP, v.10, n.2, p.249-263, maio/ago. 2018 - ISSN 1984-9605 
DHOND, Jan. La Alta Edad Media. 8 ed. Madrid: Siglo XXI, 1978.

ERIÚGENA, Giovanni Scoto. De Praedestinatione liber. Firenze: Edizioni del Galluzzo, 2003.

FLASCH, Kurt. Introduzione ala Filosofia Medievale. Torino: Eunaudi, 2002.

GENET, Jean-Pierre. Igreja e Poder. In: LE GOFF, Jacques; SCHIMITT', JeanClaude. Dicionário Temático do Ocidente Medieval vl.1. Bauru: Edusc, 2002.

GILSON, Etienne. A Filosofia na Idade Média. São Paulo: Martins Fontes, 1995.

GODESCALC D'ORBAIS. Oeuvres Théologiques et Grammaticales. Louvain: Spicelegium Sacrum Lovaniense, 1945.

GUENÉE, Bernard. Corte. In: LE GOFF, Jacques; SCHIMITT, Jean-Claude. Dicionário Temático do Ocidente Medieval vl.1.Bauru: Edusc, 2002.

KNOWLES, David. The Evolution of Medieval Thought. 2 ed. London: Longman, 2000.

MAINOLDI, Ernesto. Introduzione. In: ERIÚGENA, Giovanni Scoto. De Praedestinatione liber. Firenze: Edizioni del Galluzzo, 2003.

OLIVEIRA, Terezinha; SIBIN, Priscila. Mestre Alcuíno e a Formação da Liderança Carolíngia: uma análise de Espelho de Príncipe. Imagens da Educaşão. V.3, p. 19-29, 2013.

QUEIROZ, Tereza. Aprender a Saber na Idade Média. In: MONGELLI, Lênia (org). Trivium e Quadrivium. As artes liberais na Idade Média. Cotia: Ibis, 1999.

RIGHI, Maurício. Meta-História e História. In: DAWSON, Christopher. Criação do Ocidente. São Paulo: É Realizações, 2016.

VEYRARD-COSME, Christine. Alcuin. In: GOUVARD, Claude; DE LIBERA, Alain; ZINK, Michel. Dictionnaire du Moyen Âge. 2 ed. Paris: PUF, 2006.

VITORETTI, R.A; OLIVEIRA, T. Carlos Magno, Alcuíno e o Renascimento Carolíngio. In: Seminário de Pesquisa em Educação da Região Sul. Trabalhos Completos. Florianópolis, 2002, v.1.

Submetido em: $28 / 11 / 2017$

Aceito em: 09/01/2018

Publicado em: 15/10/2018

Filos. e Educ., Campinas, SP, v.10, n.2, p.249-263, maio/ago. 2018 - ISSN 1984-9605 